Samu Niskanen

\title{
The Emergence of an Authorial Culture: Publishing in Denmark in the Long Twelfth Century
}

This essay seeks to outline how the publication of original Latin literary works began and matured as a process in Denmark in the course of the long twelfth century. ${ }^{1}$ Characterized by cultural and societal transformations in Western Christendom, the period witnessed the emergence of a Latin literary culture in Scandinavia. The present paper's geographical focus is on Denmark because, in comparison with other Scandinavian realms, the kingdom was a forerunner in the field of Latin composition. ${ }^{2}$ The corpus of texts discussed embraces selected Latin literary works from Denmark datable to the long twelfth century. The principle governing the selection was that the texts furnish evidence regarding their publication and are representative of pertinent key trends. The corpus tends towards the hagiographical and historical, rather than the theological and scholarly, because writings falling into the former categories were authored throughout the period under study. The earliest text in our corpus is an anonymous hagiographical text from the turn of the eleventh century; the latest is the Gesta Danorum of Saxo Grammaticus, published in 1208 or soon after.

Before embarking on the analysis, I must clarify how the terms literary and publication are applied here, and how the subject is approached. Literary here denotes texts that were transmitted by means of books or booklets (as opposed to inscriptions), that were not produced in the course of business and were characterized by at least a degree of commitment to elegance of expression (as opposed to administrative documents), and that were longer than a few lines. The term publication calls for a more detailed treatment; a short overview of previous research on authorial publication in the Middle Ages is likewise necessary. Today, the vehicle for publishing is a printed or

1 This project has received funding from the European Union's Horizon 2020 research and innovation programme under grant agreement no. 716538 (MedPub, Medieval Publishing from c. 1000 to 1500). I am indebted to Jakub Kujawinski, Lars Boje Mortensen, the editors of this book, and the two anonymous reviewers for their comments. Any remaining errors are mine.

2 This assessment pertains to quantity and variety. The earliest Scandinavian literary text in Latin was composed possibly in mid-eleventh-century Norway; see Mortensen (2012: "Sanctus Olavus"): Missa. For twelfth-century texts in Norway, see also Mortensen (2012: "Sanctus Olavus") and Ommundsen (2012: “Sanctus Hallvardus”): Vita and Officium. For Sweden, see Ståhl (2012: "Sanctus Bodvidus”) and Haki Antonsson (2012: "Sanctus Ericus”). For Iceland, see Egilsdottir (2012; "Sanctus Thorlacus Thorhallson").

Samu Niskanen, University of Helsinki

Ә Open Access. (C) 2021 Samu Niskanen, published by De Gruyter. (c) BY-NC-ND This work is licensed under the Creative Commons Attribution-NonCommercial-NoDerivatives 4.0 International License.

https://doi.org/10.1515/9783110695366-004 
digital book, rather than a manuscript. ${ }^{3}$ In the context of modern publishing, the word manuscript stands for "an author's handwritten or typed text that has not yet been published", as the Oxford Dictionary of English puts it. Many would instinctively equate manuscript with the quality of not being published. Some scholars have accordingly considered the word publishing inappropriate in pre-print contexts. The majority opinion today, so it seems, is otherwise: publishing as a term is applicable to manuscript cultures. ${ }^{4}$ I am in favour of that latter position. I define publishing for the purposes of this paper as follows: the word denotes here an authorial act of releasing a work to a public. The vehicle was a manuscript, on occasion supported by voice (if the event of release involved reading in public). Release could naturally have been repeated, resulting in "a series of publishing moments" for a single work. ${ }^{5}$ While that aspect of repeated acts is important for attempts to conceptualize medieval publication, the thin manuscript evidence for the works to be studied below does not provide for pertinent discussion here. We shall, however, encounter a fragment of an unpublished text, testifying to processes prior to publication in manuscript.

Furthermore, the essay cannot delve into another key feature that makes medieval publication fundamentally distinct from mass-produced prints. This is the fact that textual variation is a virtually inevitable side-effect of the process of copying by hand. All medieval authors were certainly aware that in the course of transmission, writings would become subject to scribal inaccuracy and intervention. In some cases, departures from an authorial text were so radical that its descendants should be classified as adaptations rather than copies. An unpolished authorial text and failure to claim authorial ownership - i.e. issuing a work anonymously - was a combination that could turn copyists into redactors. ${ }^{6}$ Some authors took efforts to prevent such vagaries. Prologues to their works urged, for instance, that the whole text must be copied, including its prefatory devices such as the proem and the list of chapter headings. ${ }^{7}$ None of the authors to be discussed below did this. ${ }^{8}$ It should be emphasized, however, that the sample is far too small to indicate that twelfth-century writers in

3 For a more detailed discussion of scholarship on publishing in manuscript cultures, see Tahkokallio (2019: 3-9); Hobbins (2013: 153-154); Tether (2014: 23-26; 2017: 13-26); Sharpe (2009: 1-2).

4 See e.g. Laidlaw (1987: 35-75); Doyle (1989: 109-123); Riddy (2004: 29-49); Hobbins (2013); Sharpe (2009); Tether (2014; 2017); Dunning (2016).

5 The phrase "publishing moment" is introduced in Hobbins (2013: 152-182).

6 See e.g. Niskanen (2019: 103-114). One of the earliest historians of the First Crusade implied that an incentive for him to write was the anonymity of the writer of his main source (Historia Ierosolimitana: 4).

7 For near-contemporary instances, see Anselm of Canterbury (Sancti Anselmi Opera: Monologion, Prologus (vol. 1: 8); De ueritate, Praefatio (vol. 1: 174); Cur Deus homo, Praefatio (vol. 2: 43)).

8 Note that at the close of his Lex castrensis, Sven Aggesen, one of our authors, invited readers to elaborate the treatise, which should primarily be taken as a demonstration of humility, a common literary trope (Lex castrensis: 43). 
Denmark would not have been concerned about textual variation in the course of transmission. Furthermore, provincialism would hardly have accounted for such a lack of concern. A Scandinavian writer operating in a far remoter context, the Icelandic abbot Bergr Sokkason ( $†$ c. 1350), prefixed a letter to his Nikulás saga erkibyskups, entreating that his audience say Ave Marias for his soul. Hence, he insisted that copyists not leave out the prefatory letter. Bergr's pious request was a success in that $\mathrm{Ni}$ kulás saga erkibyskups, together with the letter, is preserved in an unusually precise antiquarian copy, Reykjavík, Stofnun Árna Magnússonar, AM 638 4to.

In outlining how Latin literary publishing took hold in Denmark, the present paper attempts a theoretical contribution. It aims to categorize those types of publishing that emerge from the texts studied. The emphasis is on the social aspect of publishing; the exercise concentrates on the engagement of third parties in authorial publication. This approach is necessitated by the paucity of source material, especially contemporary manuscript witnesses. The evidence comes almost exclusively from prefatory texts with which medieval authors equipped their works. These typically identify individuals and institutions that were in some way relevant to publication. More often than not, such parties were dedicatees, who were, at least in theory, the first to receive the finished work. A dedication conspicuously stated in a preface informed readers of the social and/or institutional context in which the work in question had, in actual fact or purportedly, been released. Pertinent remarks abound in medieval prefaces to an extent that suggests two corollaries; one is potentially positive, and the other is potentially negative. The former is that even the absence of references to third parties relevant to publication may be instructive. This is something that will be proposed below.

The latter, potentially challenging quality is that statements on dedication and commission were first and foremost literary gestures, deriving from the Latin classics and tending towards affected modesty. Dedications, which were more frequent than statements of commission, were often addressed to parties superior to the author. One function of dedicating, then, was to convince readers that the writer belonged to important circles. The snag is the fact that dedications and commissions were almost exclusively reported by authors, who would benefit from prestigious connections. Such circumstances would have encouraged distortion. As a result, medieval dedications have sometimes been dismissed as evidence of historical realities. ${ }^{9}$ Nonetheless, being formulaic does not necessarily equate with being inaccurate. A recent study on three twelfth-century Anglo-Norman historians demonstrates that they sought, at times with success, to obtain concrete benefit from high-standing individuals to whom they dedicated their works. Dedications were genuine in their case (Tahkokallio 2019: 79-80). Furthermore, even fictitious testimonies serve some purpose. A dedication to

9 See e.g. Curtius (1961: 95). 
an eminent party could have furnished a work with a certain aura of authority, even if no actual relationship between the author and the dedicatee existed. Feigned connections should be considered as belonging to authorial efforts to publish and gain readership. While it may be challenging to assess how accurately remarks on dedication and commission matched the actual reality, they can and should be taken as evidence of social evaluations relevant to publishing.

Although the modern discussion of authorial manuscript publishing began more than a century ago, the act of publication - the step that carries a new text from author to audience - in the Middle Ages is mostly unexplored (Root 1913: 417-431). The most recent edition of Saxo Grammaticus' Gesta Danorum is demonstrative of the current situation. The edition represents the cutting edge of today's textual scholarship, to which glowing reviews and awards attest. The introduction, which is extremely learned, makes no comment on how Saxo published. ${ }^{10}$ Such an approach is typical of modern critical editions. The acts through which authors released their works are rarely scrutinized. Attempts to conceptualize medieval publication are even rarer, even though the first concentrated scholarly effort, by Robert Root, sought to classify various types of publishing in the manuscript age. ${ }^{11}$ The present paper continues that discussion. Three types of release will be put forward: issuing (contrasting with publication proper), donative publication, and independent publication. In comparison to the classifications of Root, who was a philologist, mine focus more on the institutional setting of release. What follows is a historian's attempt to conceptualize authorial publication in the Middle Ages. It should also be emphasized that my classifications are intended neither to be comprehensive nor universal. A central aspect of medieval publishing was its responsiveness to the contingencies of time and place, as will be briefly argued in the final section of this paper. ${ }^{12}$ To conclude, the aim here is to propose categories of how works were released that help us characterize the earliest history of authorial publishing in Denmark. The most profound trend to emerge is increasing authorial self-assertion.

It should be emphasized that the following discussion does not cover intended audiences that could not be immediately reached through acts of publication. All the writers to be considered probably hoped not only to secure a contemporary reception in their immediate circles but also to erect monuments for posterity. Such considerations would have affected how some of them released their works. Yet

10 The closest we get is a discussion of the time of composition concerning Saxo Grammaticus (Gesta Danorum: xxxiii-xxxv).

11 Root (1913) proposed a fourfold classification: publication by presenting a text to a patron, publication by public reading, publication sanctioned by a religious authority, and commercial publication by making the text available to urban professional scribes. For a critical assessment, see Riddy (2004: 30-37).

12 My view resonates with Eisenstein (2016: 8), although I do not share her scepticism. 
causalities of this nature are hard to establish, for which reason the subject must go undiscussed here. One should keep in mind, however, that the writings categorized below as relevant to specific institutions were probably also composed with an eye on external readerships in the future.

\section{Passio sancti Kanuti regis et martiris: issuing}

As far as the surviving evidences goes, the earliest piece of Latin literature from Denmark is the Passio sancti Kanuti regis et martiris, a hagiographical work whose protagonist is King Canute IV († 1086). ${ }^{13}$ The composition is datable to $1095 \times 1101$. We do not know who the author was. On account of his open hostility to the Normans, it has been conjectured that he was possibly an Anglo-Saxon emigrant from England (Haki Antonsson 2012a: “Sanctus Kanutus Rex"). His anonymity may have to do with the genre of his writing. Hagiographical pieces were often, but (as we shall see) not always, anonymous. The Scandinavian corpus of Latin literature is a demonstration of this state of affairs. The Medieval Nordic Literature in Latin database, which is the best available bibliography and embraces roughly 80 per cent of the total corpus, itemizes 108 Latin authors and writings. While anonymous hagiographical works, many consisting of various sections such as legenda and officia, amount to twentytwo, those by identifiable authors are ten in number. ${ }^{14}$ Hagiographical works, especially those by unknown authors, were often composed for a specific purpose and audience, typically an ecclesiastical community that used the text in its ritual life. Such qualifications apply to the Passio sancti Kanuti regis et martiris. The text reads as a set of homilies, providing for lectiones at matins (Sønnesyn 2016: 135). This liturgical association is reflected by the medieval reception: the subsequent Breviarium Arhusiense, Breviarium Lundense, and Breviarium Nidrosiense adopted parts of the work as lectiones (Haki Antonsson 2012a: "Sanctus Kanutus Rex"). The first sentences of the Passio sancti Kanuti regis et martiris, and its historical context, suggest that it was to serve in the veneration of St Canute in a specific community. The passage in question deserves to be quoted here because of the fact that it inaugurated Latin literature in Denmark. It may be added, because the fact has gone unobserved in previous scholarship, that the opening sentence was lifted from Alcuin's homily for the

13 Passio sancti Kanuti regis et martiris (62-76); see also Mortensen (2006: 247).

14 These figures are only provisional. The figure of twenty-two counts different texts on an individual saint as one. The figure of ten does not include sermons, which are not thoroughly catalogued in Medieval Nordic Literature in Latin (https://wikihost.uib.no/medieval/index.php/ Medieval_Nordic_Literature_in_Latin). 
anniversary of St Willibrord (Omelia: $138-139) .{ }^{15}$ In other words, Latin literature in Denmark was ushered in with a quotation from a central Carolingian author.

Licet per totius orbis ecclesias conueniat omni populo christiano festa sanctorum celebrare, uictorias martirum laudare uitamque istorum imitari, in singulis tamen locis propter familiaritatem cohabitantium et propter sanctarum presentiam reliquiarum, que in solacium istis uel illis habitatoribus condonate sunt, ueneratione (inquam) speciali apud ciues populosue suos digni habentur atque honorantur. Omnium ergo uirtutum opifice spiritu sancto aspirante nunc de sancti Kanuti regis ac martiris tractaturi passione ammonemus uel obsecramus uos, qui hec audituri estis [. . . . ${ }^{16}$

(Passio sancti Kanuti regis et martiris: 62)

It is customary that throughout the churches in the entire world, Christian people assemble to celebrate the feasts of saints, praise the victory of martyrs, and imitate the lives of the righteous. Yet, I should say, among the inhabitants or people of certain places [certain saints] are regarded and revered as having special honour by virtue of familiarity between them and their compatriots and the presence of their holy relics, which have been given to the inhabitants of the place in question for consolation. Therefore, by the inspiration of the Holy Spirit, the source of all virtues, as we are to explore the passion of St Canute, the king and martyr, we urge and request that you, who will be listening to this [. . .].

As noted in several studies, the context of the Passio sancti Kanuti regis et martiris was the church of St Mary and St Alban in Odense, where King Canute had been slain and where his relics were held (Haki Antonsson 2012a: "Sanctus Kanutus Rex"). Given that the author had participated in the translation of St Canute's relics to the said church in 1095, he apparently belonged to its fraternity (Passio sancti Kanuti regis et martiris: 71). But how was the work released for reception? Not identifying himself, the writer did not claim any authorial ownership. Nor did he remark on his authorial process or how he made the work available. Faced by the absence of evidence, one must proceed by way of deduction. Anonymous pragmatic literature that had been composed to meet the needs of a community must often have been released in a casual manner. It would have been natural to bring such writings into use with no or little ceremony to mark the occasion. The odds are that the Passio sancti Kanuti regis et martiris was released more or less along these lines in the church of St Mary and St Alban in Odense. The work is likely to have been aired as homilies, or lectiones, from a pulpit. Nothing suggests that the release constituted a conscious act of publishing to obtain written circulation. The noun issue and the verb to issue seem to convey such a setting more accurately than do the words publication and to publish. These deductions are applicable at least to some of the other anonymous twelfth-century hagiographical works. Their writers' shared disregard for authorial recognition suggests that when writing, they identified themselves more

15 Slighter affinities with other texts have previously been identified, see Gertz (1907: 67, note 1); Mortensen (2006: 248); Friis-Jensen (2006: 195, note 2).

16 For a recent discussion of the passage, see Mortensen (2006: 248). 
as servants of their home institutions than as authors. Their writings were likely to have been issued rather than published.

\section{Alnoth and Robert of Ely: donative publication}

King Canute proved a persistent figure in Danish Latin literature. Denmark's first identifiable Latin author likewise wrote on him; the work in question is the Gesta Swenomagni regis et filiorum eius et passio gloriosissimi Canuti regis et martyris, hereafter Gesta et passio. ${ }^{17}$ We are now furnished with key coordinates relevant to publication: we know who wrote the work and to whom it was dedicated. The writer was called Ælnoth. The work can be securely dated to the period from 1104 to 1125 . A recent conjecture, which I find persuasive, narrows this down to the years 1110 and 1113 (Gelting 2011: 38-39). Ælnoth did not identify his ecclesiastical status other than by vague expressions, laden with affected modesty. Yet he made it manifest that he was not a native of Denmark but an Englishman from Canterbury. This detail seems to have been of some significance to him, as he cared to mention it twice (Gesta et passio: 77,135 ). While Ælnoth's English background has been discussed in a number of papers, a fresh connection can be propounded. By his own account, he had been living in Denmark for almost twenty-four years when writing (Gesta et passio: 77). The combination of the timing of Ælnoth's move from Canterbury to Denmark and the recently proposed termini of 1110 and 1113 for his writing hints that he may have been implicated in a revolt at St Augustine's at Canterbury. In 1087, the monks of that house rebelled against their new abbot, Wido, a Norman monk. While some monks returned to their house without sanction, punishments were imposed on those who persisted in resistance. Ill-will lived on. In 1088, a party devised a secret plan to physically harm the abbot. The plot proved futile, and the culprits were caught. The retribution was harsh (Acta Lanfranci: 84-89). ${ }^{18}$ Ælnoth might have been a monk who was exiled or fled from Canterbury. That background would account for his antipathy towards the Normans (Gesta et passio: 96-97). Yet Ælnoth refers to himself as a priest, never as a monk or brother, in the Gesta et passio. He may not have lived as a cloistered monk in Denmark, but as a royal chaplain, an argument put forward already in the nineteenth century and reasserted recently with fresh circumstantial reasoning (Gelting 2011: 39-41). Such a status seems to be incompatible with a recent judicious characterization of Ælnoth as a writer, according to which he "wrote within a tradition profoundly informed and animated by monastic ideals" (Sønnesyn 2016: 146). While my conjecture that Ælnoth was perhaps an ex-monk of St Augustine's is beyond verification, it has the merit of harmonizing the quoted assessment of him as author with what we

17 For a recent discussion, with references to previous scholarship, see Conti (2010: 189-218).

18 For modern commentary, see Sharpe (1995: 5) and Hayward (2004: 141-160). 
know of his trajectory for certain. What is more, the identification of $Æ$ lnoth as an exmonk of Canterbury resonates with advice Archbishop Anselm of Canterbury gave to Archbishop Asser of Lund by letter at some time between 1104 and 1109. The latter should "cleanse the kingdom of apostates [. . . who are] foreign [. . . and] expelled by their bishops". 19

Elnoth's Gesta et passio was associated with the brethren of St Canute's Priory in Odense. His baroque literary idiom makes it somewhat difficult to establish precisely how this relationship functioned, but it is patent that the project served the cause of that church. We can safely assume that the Gesta et passio was written under the aegis of the brethren of St Canute's, and perhaps at their invitation. ${ }^{20}$ The work opens with a dedicatory letter to King Niels (1104-1134). Ælnoth hoped that his writing would "exhilarate" the king and "inspire him to emulate the virtues of his kinsman" St Canute. ${ }^{21}$ Moral edification was something of a sine qua non for medieval historical writing of any kind, be it hagiographical or secular. A more concrete objective was that the king would make "fitting donations" to the Odense brethren, the keepers of St Canute's relics. ${ }^{22}$ The context of that request was King Niels's patronage of St Canute's Priory in Odense, which manifested itself in massive gifts. A key substratum in Ælnoth's dedication of his work to the king was, then, the medieval system of gift-giving. "Give and ye shall receive", instructs the Bible, and that is what medieval people did. Reciprocal gift-giving was a very serious business in quantity and value. Exchanges of donations were the glue that held medieval networks, even societies, together. ${ }^{23}$ Receiving material gifts from the king, St Canute's Priory was to repay, but not in kind. The brethren offered the king their prayers and, so it seems, a literary testimony to the sanctity of his predecessor.

19 Sancti Anselmi Opera (vol. 5: 394-395; Ep. 447): “[. . .] regnum illud uestro sancto studio emundetis ab apostatis, ut nullus alienigena ibi recipiat aliquem ecclesiasticum ordinem, quia illi qui ab episcopis suis repelluntur, illuc pergunt et execrabiliter ad diuersos ordines sacrantur".

20 Gesta et passio (79): “[. . .] quę de gestis religiosi principis et deo dilecti martyris probabilibus personis utriusque sexus et ordinis referentibus agnoui, religiosi habitus uiris, Ihesu Christo ibidem insignique triumphatori deseruientibus, obnixe suffragantibus posterorum memorię reseruanda apicibus contradidi [. . .]". Conversely, obnixe suffragantibus could be construed as connected to the end of the quoted extract rather than to religiosi habitus uiris as follows: suffragantibus apicibus obnixe contradidi, or 'I strenuously laid out in praiseful words'. In that case, religiosi habitus uiris should be read as the dative, expressing to whom Ælnoth wrote.

21 Gesta et passio (79): "[. . .] ea pietati maiestatis uestrę representans, ut et de tanti germani glorificatione plenius exhilaretur et ad eiusdem uirtutis insignia emulanda superno prouisore aspirante ardentius incitetur".

22 Gesta et passio (81): "Tanti igitur germani pignora regia condignis adornet donis potentia, edis sacrę decus amplificet, spiritualis normę uiros cultui ibidem diuino iugiter insistentes solidando corroboret, ut pro temporalis suffragij amminiculo superne remunerationis in ęternum potiaris premio". 23 Scholarly discussion on gift exchange in the Middle Ages is a massive field. For an overview, see Bijsterveld (2007: 17-50). The gift-exchange aspect has not been fully explored in studies on medieval publishing and literary patronage. 
Ælnoth's Gesta et passio is demonstrative of the fact that literary dedications did not necessarily bring together writings and the readerships intended for them. The complexities of Ælnoth's style emphasize the lack of an effective connection between his work and its dedicatee. ${ }^{24}$ King Niels, the dedicatee, hardly belonged to the class of men at whom Ælnoth directed his piece. Almost certainly illiterate, the king knew a few Latin words at best. ${ }^{25}$ Ælnoth's diction is considerably artificial, such that only able Latinists can enjoy, or fully comprehend, his narrative. Oral renditions in the vernacular may perhaps have been envisaged, so that the text would have served as "a memory aid for a vernacular storyteller". ${ }^{26}$ But even that would have been a challenging task in anything but a simplified paraphrase. Be that as it may, Ælnoth crafted his Latin diction with men other than his king in mind. The readership intended for the Gesta et passio must have consisted of the learned elite of the brethren of St Canute's Priory and other churches, and perhaps a very few clerics at the royal court. The king's primary role was to receive the work as a gift and in so doing participate in its publication.

Flnoth did not make explicit remarks on how the Gesta et passio was put into circulation. Our two extant manuscripts do not provide any insights either; they are too late. As regards subsequent transmission, they mirror an entirely monastic affair, resonating with our identification of Ælnoth's primary intended audience. ${ }^{27}$ Our only piece of evidence in relation to the act of publication is the work's dedication to King Niels. That dedication, conspicuously displayed, communicated to medieval readers the understanding that the work had been released in the presence of the king. Such an event would not have been a rarity, as is clear from the great amount of medieval depictions of kings, and other magnates, receiving books as donations. So, at least in the medieval imagination and probably in reality, King Niels had been presented with a copy of the work. Ælnoth - or possibly the brethren of St Canute's, the ultimate beneficiaries from the work's royal dedication - would have given it to him in person.

Another hagiographical work, the Life of Canute Lavard, may be briefly commented on at this juncture, as its background resembles that of Ælnoth's Gesta et passio. The Life of Canute Lavard only survives in fragments incorporated into other

24 For his style, see Winterbottom (2016: 119-130).

25 Bäuml's term semi-literate probably has less relevance to early twelfth-century contexts in Scandinavia than on the continent, especially those where the vernacular was Romance; see Bäuml (1980: 246-247).

26 The terminology is from Mortensen (1995: 99).

27 The two survivors, St Omer, Bibliothèque municipale, MS 716 and Bruges, Openbare Bibliotheek, MS 403, come from the Cistercian houses of Ter Doest and Clairmarais respectively. The St Omer manuscript is datable roughly to the final decades of the twelfth century and the Bruges manuscript to the turn of the twelfth century. Both manuscripts transmit the Legendarium Flandrense, a vast compilation of saints' lives. The Gesta et passio is embedded in that collection, a context that was certainly established decades after Ælnoth's career. 
works. While no source transmits the work's title (and hence the English title here), we know that it was authored by Robert of Ely at some time between 1135 and 1137 (Canute Lavard: 234-241). Robert of Ely was an English emigrant well versed in Latin composition. His Life of Canute Lavard was dedicated to King Eric II (1134-1137) (Canute Lavard: 234). The project was certainly associated with Ringsted Abbey (OSB), which Eric II founded on the site of an older priory in 1135. The church was the resting place of Canute Lavard, a prince who had been killed in 1131. It is not known whether or not Robert was affiliated to Ringsted Abbey (Friis-Jensen 2012). Either way, the Life of Canute Lavard was probably a commission from the abbey's brethren or, perhaps less likely, written at the invitation of the king, who would have profited from promoting Canute Lavard, his kinsman. A pattern emerges. Latin authors in Denmark were English clerics, suggesting that the native clergy was lacking in linguistic skills. Their writings were connected to monastic communities closely associated with their saintly protagonists and to royal patronage of the houses in question. One factor was the exchange of gifts between the king and the monasteries of St Canute's Priory in Odense and Ringsted Abbey. I would propose that the aspect of gift-giving was so significant that we can characterize the release of Ælnoth's Gesta et passio and Robert of Ely's Life of Canute Lavard as donative publication. The classification is tentative, especially for Robert of Ely's work.

\section{Sven Aggesen: independent publication}

Within a generation or so of its inception in Denmark, Latin composition began to diversify in terms of geography, institutional setting, and genre. The earliest surviving historical piece that cannot be classified as hagiography is the Chronicon Roskildense, composed c. 1138. The work was followed by other chronicles such as the Chronicon Lethrense, and various annals known today by the generic title Annales Danici. These writings resembled the hagiographical tradition in that the writers did not identify themselves. Their anonymity emphasized the fact that they were compilerscum-authors, lifting material from other works. Some of these histories were related to one another in ways that are hard to establish (Kristensen 1969). The most significant centres were the cathedrals of Roskilde and Lund, secular churches contrasting with the regular status of St Canute's Priory in Odense and Ringsted Abbey. Lund became a hub of annalistic writing, which was being practised there from 1140 to 1265 (Kristensen 1969: 150). The annalistic tradition stimulated more ambitious historiographical endeavours launched in the 1180s. Two men associated with the entourage of the archbishop of Lund wrote national histories. They were Sven Aggesen and Saxo Grammaticus. In contrast to previous literary works from Denmark, theirs testify to a self-contained sense of authorship, something that their publication bore out. 
The years of Sven Aggesen's life are unknown, but he was certainly active in the 1180 s. $^{28}$ His family represented Denmark's highest nobility. He was probably an archdeacon of Lund, then under Archbishop Absalon. ${ }^{29} \mathrm{He}$ is known to have written three pieces: Lex castrensis sive curiae (a law code, henceforth Lex castrensis), Genealogia regum Daniae (of which only fragments survive), and Historia regum Daniae compendiosa (henceforth Historia compendiosa). The secure termini for the Lex castrensis are 1181 and 1201. Because this work patently preceded the Historia compendiosa, it is likely to have been composed in the 1180s. The Historia compendiosa was written at some time between 1185 and 1202, and can be dated tentatively to c. 1188 (Christiansen 2012: "Sueno Aggonis"; 1992: 25-26).

The Lex castrensis and Historia compendiosa open with prologues. They make no mention of third-party involvement in the publication process. Sven presented his works neither as commissions nor as having been dedicated to someone. Indeed, he made it clear that his writing stemmed not from external requests but from his own inclination. ${ }^{30}$ He intended the Lex castrensis for 'budding youths who flourish in the art of eloquence' (i.e. schoolboys) and posterity. He did not define target readers for the Historia compendiosa. Whoever they were, their number was not large, a condition strengthened by Sven's convoluted Latin diction. Most or all of them would have been associated with the Lund cathedral and other major churches, and perhaps the royal court. ${ }^{31}$

The absence of references to patronage or other relevant third-party commitment to the authorial process is significant in respect to publishing. Under such circumstances, the release of a work, as conveyed to readers by implication, was an independently conducted affair. While publication, if successful, must in effect have involved some external participation, uncredited parties did not belong to the dramatis personae of the authorial narrative of how Sven's works had begun their journey to the reader. His decision not to acknowledge external engagement implied that publication had been arranged by him alone. This impression is consistent with the manner in which he preserved his works for posterity. Two references to his own work, which are found in the Lex castrensis and Historia compendiosa, indicate that he had made an anthology. The reference in the Lex castrensis explains that "at the end of this little work the pedigrees of the kings and their succession" would be

\footnotetext{
28 He must have been older than Saxo; Sven's father was an active warrior in 1132, whereas Saxo's grandfather fought for Valdemar I, possibly after 1157.

29 These biographical details come from Eric Christiansen (1992: 1-4; 2012: “Sueno Aggonis”).

30 The observation was first made in Christiansen (1992: 4). Historia compendiosa (46-47).

31 Lex castrensis (12-13, 42-43). It has been argued that Sven wrote for "a select audience of educated initiates" or "a very restricted elite"; see Christiansen (2012: "Sueno Aggonis") and Mortensen (2011: 69).
} 
unfolded. $^{32}$ The reference is either to the Historia compendiosa or, less likely, the Genealogia regum Daniae. That reading resonates with our only manuscript witness of Sven's oeuvre, Copenhagen, Arnamagnæan Institute, AM 33 4to, datable to the seventeenth century. This book arranges the three works in the following order: Lex castrensis, Historia compendiosa, and Genealogia (edited and expanded by an unknown author). The second reference is unambiguous and as such more instructive. It can be quoted here in full.

Hic primus, dum in Anglia pacis tranquillitate poteretur, leges condidit castrenses, quas pro modulo ingenioli mei supra libaui. ${ }^{33}$

While he enjoyed the calm of peace in England, he was the first to make laws for retainers, which I have outlined above according to the small measure of my slight abilities.

The reference is found in the middle of the Historia compendiosa and is to the Lex castrensis. The emphasized word supra implies that the two works were accessible in one manuscript. This minute detail is of significance to us because it demonstrates that Sven assumed his writings would also be available together for his readers. He did not publish the Historia compendiosa singly. Such a method of authorial preservation betrays a writer who regards his works as a coherent body. Sven considered that his oeuvre constituted a discrete legacy, to be handed down as a whole. This can be taken as testimony to a developed sense of authorship. The mode of transmission also emphasizes Sven's own efforts to preserve his works. There is nothing in this meagre evidence to suggest that they would have circulated separately from one another.

Authorial anthologization characterized by internal references was by no means unique to Sven. The method was convenient for minor authors. One instance is Ralph of Battle († 1124), a monastic author from Anglo-Norman England, whose treatises were circulated as an organic whole in a single book (Niskanen 2016: 220). In his case, like Sven's, the approach proved rather ineffective. The manuscript transmission of Ralph's treatises was a much more limited affair than that of his prayers (Niskanen 2016: 201-202). Sven's works seem to have failed almost completely to obtain contemporary dissemination. They survive, as has been said, in a single manuscript, which dates from the early modern period. He was read by Saxo, whom he knew in person, but traces of reception by other medieval authors have not been detected (Christiansen 2012: "Sueno Aggonis").

Sven's assertion that he wrote of his own volition, his silence on external patronage, and his anthologization of his oeuvre are relevant to his approach to publication.

32 Lex castrensis (12-13): regum genealogias regnorumque successiones circa finem huius opusculi explicabo.

33 Historia compendiosa (84-85). The English translation, which I have modified slightly, is from Christiansen (1992: 63). 
On the basis of these aspects, it would appear that the release of the Lex castrensis and Historia compendiosa should be categorized as independent publishing. The conclusion must, however, be qualified with respect to the preservation of his works for posterity. It was a universal condition in the Middle Ages that books stored in the libraries of institutions had much better chances of survival over a long period of time than those in any other kind of ownership. This law also applied to societies and literary circles more sophisticated than those of high medieval Denmark. For instance, the celebrated humanists Petrarch and Boccaccio thought that in Renaissance Italy the best way to ensure the preservation of their writings for future generations was to consign them to a religious institution (Regnicoli 2013: 387-393). So, some dependence on the established structures of his home institution, which was probably the Lund cathedral, must have been necessary for Sven as an author. ${ }^{34}$

Sven's case demonstrates that towards the end of the twelfth century, a Danish writer could exclusively cite his calling to assume an authorial identity. Although Sven's independence was of course only relative, it contrasts with the obvious institutional character of his predecessors' status as writers. Sven operated in a milieu that provided more room to entertain and pursue one's literary ambitions. He was also fortunate to possess a substantial asset that would have contributed to his liberty to realize personal preferences. Bonds of blood were critical to one's prospects in the Middle Ages. A clerical immigrant without family ties to local clans, such as Ælnoth and Robert of Ely, would essentially remain a client. Coming from a powerful family, Sven would have had a variety of prospects that had not been available to the two Englishmen. A case in point is the fact that he was able to accomplish his literary project without the need to find a patron.

\section{Saxo Grammaticus}

The Gesta Danorum of Saxo Grammaticus towers over all other Latin compositions from Denmark. The work is an exceptionally grand history, stretching from mythological days of yore to Saxo's own times. The most recent edition, including a facing-page English translation, runs to 1,539 pages. Prose is interspersed with poetry. ${ }^{35}$ Interludes with wider geographical perspectives feature. ${ }^{36}$ Saxo began writing in about 1188 at the latest and completed the project in 1208 at the earliest (Gesta Danorum: xxiii-xxiv). The prologue to the Gesta Danorum asserts that it was a commission from Archbishop Absalon of Lund (1177-1201) (Gesta Danorum: Pr. 1. 1). A foremost protagonist of the so-called Valdemarian Age (a period characterized by the consolidation

34 For an argument emphasizing Sven's institutional associations, see Mortensen (2011: 67-70).

35 A course of action stated in the prologue: Gesta Danorum (Pr. 1. 3).

36 Again a stated course of action: Gesta Danorum (Pr. 2. 6-8). 
of royal and ecclesiastical institutions, and their cooperation), the archbishop was a very mighty patron. His lordship was second only to that of King Valdemar I "the Great" (1154-1182), to whom he acted as the principal adviser. While reports of commissions received from high-ranking parties were a cliché in medieval prefaces, strong circumstantial evidence validates Saxo's testimony. A comment by Sven Aggesen verifies by implication that Absalon not only knew but also approved of Saxo's project. Indeed, the passage in question could be read as stating that Absalon was Saxo's source and commissioner. ${ }^{37}$ It is evident that Saxo consulted Absalon in person when recounting the archbishop's exploits under Valdemar I; it can plausibly be argued that the chapters in question were Absalon's own memoirs written down by Saxo under his oversight. $^{38}$ There was also an official connection between the men. Making his career in the Lund cathedral, Saxo operated in close proximity to the archbishop, to whom he served as secretary. The epithet 'Grammaticus' suggests that at some point he may have taught at the cathedral school. Saxo was, no doubt, one of the canons of the chapter of Lund, a post which offered access to the archbishop and other magnates (Gesta Danorum: xxix-xxx).

While the context of Saxo's career was the archbishop's household, the Gesta Danorum was not directly associated with the cause of the Lund cathedral, or any other particular church for that matter. In this respect, Saxo's undertaking, like that of Sven Aggesen, contrasted with the undertakings of Ælnoth and Robert of Ely, whose hagiographical writings served definable pragmatic purposes. Sven's and Saxo's projects were manifestations of Lund's historically oriented intellectual milieu. Archbishop Absalon certainly wielded influence therein. Taking a personal interest in recording things Danish, he composed a law code in the vernacular. ${ }^{39}$ Although Saxo's Gesta Danorum surpassed the cause of his home institution, he is unlikely to have envisaged a wide external circulation for the work. The text was too long to be copied without a notable investment of resources and time. Saxo's Latin was too complex to be rendered in translation to non-Latinate audiences without considerable effort. His narrative did not yield sections straightforward to extract (Mortensen 2019: 73-74). Readerships intended for the Gesta Danorum outside Lund must have been very limited, and Absalon seems to have had a role in reaching them. Four

37 Quorum gesta plenarie superfluum duxi recolere, ne crebrius idem repetitum fastidium pariat audientibus, cum illustri archipresule Absalone referente contubernalis meus Saxo elegantiori stilo omnium gesta executus prolixius insudabat, as amended in Karsten Friis-Jensen (1989: 334). For the ambiguous meaning of the ablative absolute Absalone referente, see Friis-Jensen (1989: 334, note 2), Mortensen 2011: 67-68), and Christiansen (1992: 127, note 121) with further references. Note that Mortensen propounds a fresh contextual reading of the passage in question. While our positions are not fully in agreement as to the level of Sven's authorial cooperation with the household of the Lund cathedral, I acknowledge that Mortensen's contextualization of Sven's and Saxo's relationship is justifiable.

38 Gesta Danorum (Pr. 1. 5 and books xiv-xvi); see Mortensen (2019: 41-46).

39 Absalon's work has not survived for us, but Sven Aggesen cited it as a source for the Lex castrensis. 
fragments of the work kept in the Royal Library of Copenhagen under the shelfmark NKS 570 fol have recently been identified as belonging to three separate books of Cistercian origin from about 1230-1260. As such, they would attest to a significant twelfth-century transmission within the network of the ten Cistercian monasteries in Denmark (Gullick 2011: 65-77). Absalon's association with the Order by virtue of his great donations to its monastery at Sorø could explain the Cistercian circulation (Mortensen 2019: 74).

Completed after Absalon's death, the Gesta Danorum was dedicated to his successor, Archbishop Anders Sunesen (1202-1228), as stated in the prologue. Like Absalon, Anders Sunesen was an extremely well-connected man of letters. Having studied extensively abroad, he composed at least three Latin works: Hexaemeron, Leges Scaniae, and a treatise on the sacraments of the Church, now lost. ${ }^{40}$ He came from a wealthy family and, prior to his election as archbishop, he had worked as a royal secretary. Referring to Anders's elevated social status, piety, and learning, Saxo hoped that the archbishop would act as a shield against potential criticisms. Entreaties to that effect were customary in medieval prefatory texts (Gesta Danorum: Pr. 1. 2). Saxo also had another dedicatee, King Valdemar II "the Victorious" (1202-1241). Unlike the archbishop, the king was not requested to contribute to the Gesta Danorum's dissemination. Rather, Saxo presented the work as rendering service to Valdemar. The Gesta Danorum depicted the king's lineage by recounting the deeds of his ancestors. In so doing, Saxo explained, he fulfilled his hereditary obligation to the Crown. That remark was designed to slip in his family's connection to royal circles, a source of pride for Saxo. Prefatory mentions of commissions and dedications were literary topoi, as discussed above, whose intention was to portray the act of publication in propitious terms. This general rule applies also to the Gesta Danorum. This is not to say that Saxo's implicit testimony regarding the social context of publication was somehow inaccurate. His career guaranteed familiarity with Archbishop Anders Sunesen and made personal acquaintance with the king entirely plausible. A great achievement in every respect and a monument to the triumphs of Valdemar's predecessors, the Gesta Danorum was an adornment to his monarchy.

How the Gesta Danorum was presented to its dedicatees cannot be known, but I am willing to speculate. While primary copies do not survive, four leaves of a working copy have come down to us. ${ }^{41}$ The leaves constitute the so-called Angers Fragment, Copenhagen, Royal Library, NKS 869 g 4to. The Angers Fragment is not necessarily Saxo's autograph in the precise sense of the word. The script dates from his time, but we do not possess a control to verify whether or not the hand was his. The text may have been copied from his dictation or an earlier draft under his oversight. That the

40 For a survey of his oeuvre, see Ebbesen (2012: “Andreas Sunonis”).

41 What follows in this paragraph relies on Gesta Danorum, Introduction (lii-liii; with references to previous scholarship). 
fragment comes from his workshop has been established from textual evidence. The leaves carry two layers of writing: the main text and insertions executed between lines and in the margins. The interlinear and marginal insertions are stylistic revisions. They contain borrowings from Justin and Valerius Maximus, on whom Saxo modelled his Latin diction. The finished version of the Gesta Danorum, transmitted via another route, combines formulations from the fragment's main text and its insertions, and also includes material found in neither. The main text in the Angers Fragment is, then, an early draft, while the interlinear and marginal insertions represent authorial editing. The final version would have been worked up from these two layers of material and further modifications.

My interest is the layout of the Angers Fragment, to which less attention has been drawn than its texts. ${ }^{42}$ The leaves, slightly trimmed, measure $c .20 .5 \times 14.5 \mathrm{~cm}$. The space between lines is unusually large, and the outer margin is spacious. A page only accommodates fifteen rather short lines of main text. In terms of the ratio of the main written area to the leaf size, the layout is generous. Contemporary library books of roughly the same size could easily accommodate more than thirty lines of text, twice as many as in the Angers Fragment. The layout of the Angers Fragment betrays a book unmistakably designed as a working copy. The fragment differs from working copies I have seen of other near-contemporary authors. Their use of space is far less liberal, such that their layout does not differ markedly from what was typical of library books. Significantly, surviving working copies seem to have been such that they could have served copyists as exemplars. In contrast, the Angers Fragment, supplemented by numerous additions and failing to provide the published version, must have been followed by a clean copy. Saxo could afford a working copy written in a neat book-hand at an early stage of drafting.

Did Saxo present copies to his dedicatees? In the absence of surviving ones, the question is of course unresolvable. Yet, the odds must be that he did. The gifting of books to royal and ecclesiastical magnates was a widespread practice. The so-called Copenhagen Psalter, MS Thott 143 fol of Copenhagen's Royal Library, evidences that the custom found application in twelfth-century Denmark. Lavishly decorated in the extreme, the Copenhagen Psalter is considered to have been presented to a member of the Danish royal family. Datable to the latter half of the twelfth century, the manuscript attests to a milieu relevant to Saxo's literary career. Commanding very fine resources to produce books, he could have had presentation copies made.

I find it hard to categorize the release of the Gesta Danorum other than as testimony to a mature literary culture. Contrasting with the above-discussed writers, Saxo's authorial process and publishing were not characterized by any limiting

42 The most vigorous student of the Angers Fragments is Ivan Boserup, who has written several papers on the subject. While his approach is textual and literary, his codicological remarks are scarce. See e.g. Boserup (1981: 22). 
external factors. His project enjoyed support from his superior, but it was not connected to a discrete institutional purpose, unlike Ælnoth and Robert of Ely. In this respect, Saxo resembles Sven Aggesen. Their authorial circumstances were otherwise very different. Sven emerges as a somewhat isolated figure who did not benefit from promotion by superior parties. Claiming to be the first Latin historian in Denmark, Saxo dismissed Sven in silence (Gesta Danorum, Pr. 1. 1). The latter's lack of success in publishing was a precondition for such treatment.

\section{Conclusions and qualifications}

This essay has argued that purpose and third-party involvement can be used as variables to conceptualize how original compositions were released in the Middle Ages. Three subcategories have emerged: issue, donative publication, and independent publication. To have been issued rather than published, a literary piece must fulfil two criteria. It must primarily have a pragmatic function that the author conceived as relevant to a specific audience, most often a church. In addition, such a text should not include explicit indications of an aspiration to dissemination outside the confines of its target community. Our second category, donative publication, embraces texts that were likewise connected to the cause of an institutional body. The main point of divergence from issuing is the engagement of a third party in publishing. In most cases, this would have been a dedicatee from whom some sort of benefit was being or had been solicited. Our third category is that of independent publication. In such cases, publishing as conveyed to readers did not involve parties other than the author, in contrast to donative publication. Target audiences are likely to have consisted of authors' friends and associates. An independently published piece would, furthermore, have primarily served the author's literary ambitions rather than an institutional purpose.

No subcategory was proposed for the release of Saxo Grammaticus' Gesta Danorum. The work attests to publishing with authorial confidence, in association with the king and the archbishop of Lund, who represented the pinnacle of lordship in Denmark, and a high degree of pomp. Its publication is unlikely to have compared unfavourably with authorial publishing in regions that had shared in Latin civilization for centuries. This is not to say that other types of publishing were not to be found in fully developed medieval literary cultures. Instances of issue, donative publication, independent publication, and other types of publication abound throughout the period. But Saxo personified a climax to previous developments in Denmark.

Human action defies tight categorizations, and authorial publishing in the Middle Ages was no exception. An obvious qualification to this paper's conclusions is that modes of medieval publication constituted continuums in which one type morphed into another. Our classifications must, then, be treated as approximations, subject to 
overlaps and grey areas. Furthermore, our categories are by no means exhaustive. They do not embrace all the ways in which medieval authors released their works. The further one moves in whatever direction from Denmark and the twelfth century, the more different the circumstances. So, publication by the authors discussed here contrasted profoundly, say, with the release of the Historiarum Florentini populi libri XII by Leonardo Bruni ( $\uparrow 1444)$. Bruni published his work in instalments. These acts constituted grand municipal events, sometimes associated with major civic festivities. Whereas publishing was mainly an ecclesiastical and royal business in twelfthcentury Denmark, it could be a grand civic affair in fifteenth-century Italy. The act of publishing evolved over time, reacting to changes in the wider world. To conceptualize medieval publishing in breadth and depth, one needs different sets of typologies for different historical contexts.

\section{Bibliography}

\section{Sources}

Acta Lanfranci, ed. Janet Bately, The Anglo-Saxon Chronicle: A Collaborative Edition, iii, MS A. Cambridge: Woodbridge, 1986.

Canute Lavard = Robert of Ely, Life of Canute Lavard, ed. Martin Clarentius Gertz, 234-241. Vitae Sanctorum Danorum [VsD]. Copenhagen: G. E. C. Gad, 1908-1912.

Genealogia = Sven Aggeson, En ny text af Sven Aggesøns værker, ed. Martin Clarentius Gertz. Copenhagen: Gyldendal, 1915.

Gesta Danorum = Saxo Grammaticus, Gesta Danorum, 2 vols, ed. Karsten Friis-Jensen. Oxford: Oxford University Press, 2015.

Gesta et passio = Alnoth, Gesta Swenomagni regis et filiorum eius et passio gloriosissimi Canuti regis et martyris, ed. Martin Clarentius Gertz, 77-136. Vitae Sanctorum Danorum [VsD]. Copenhagen: G. E. C. Gad, 1908-1912.

Historia compendiosa = Sven Aggeson, En ny text af Sven Aggesøns værker, ed. Martin Clarentius Gertz. Copenhagen: Gyldendal, 1915.

Historia Ierosolimitana $=$ Baldric of Bourgueil, Historia lerosolimitana, ed. Steven J. Biddlecombe. Woodbridge: Boydell and Brewer, 2014.

Lex castrensis = Sven Aggeson, En ny text af Sven Aggesøns værker, ed. Martin Clarentius Gertz. Copenhagen: Gyldendal, 1915.

Omelia = Alcuin, Omelia dicenda die natalis sancti Wilbrordi, ed. Wilhelm Levison, 138-141. Monumenta Germaniae Historica, Scriptores rerum Merovingicarum, 7. Berlin: Weidmann, 1919.

Passio sancti Kanuti regis et martiris, ed. Martin Clarentius Gertz, 62-76. Vitae Sanctorum Danorum [VsD]. Copenhagen: G. E. C. Gad, 1908-1912.

Sancti Anselmi Opera = Anselm of Canterbury, Sancti Anselmi Opera, ed. F. Schmitt, 6 vols. Seckau, Rome, Edinburgh: Thomas Nelson and Sons, 1938-1961. 


\section{Literature}

Ásdís Egilsdóttir. 2012. "Sanctus Thorlacus Thorhallsson.” In: Medieval Nordic Literature in Latin, ed. Borgehammar et al. https://wikihost.uib.no/medieval/index.php/Medieval_Nordic_Literature_ in_Latin (1 October 2020).

Haki Antonsson. 2012a. "Sanctus Kanutus rex." In: Medieval Nordic Literature in Latin, ed. Borgehammar et al. https://wikihost.uib.no/medieval/index.php/Medieval_Nordic_Litera ture_in_Latin (1 October 2020).

Haki Antonsson. 2012b. "Sanctus Ericus." In: Medieval Nordic Literature in Latin, ed. Borgehammar et al. https://wikihost.uib.no/medieval/index.php/Medieval_Nordic_Literature_in_Latin (1 October 2020).

Bijsterveld, Arnoud-Jan. 2007. Do ut des: Gift giving, memoria, and conflict management in the medieval Low Countries. Hilversum: Verloren.

Bäuml, Franz H. 1980. "Varieties and consequences of medieval literacy and illiteracy." Speculum, 55: 237-265.

Boserup, Ivan. 1981. "The Angers Fragment and the archetype of Gesta Danorum.” In: Saxo Grammaticus. A Medieval Author between Norse and Latin Culture, ed. Karsten Friis-Jensen, vol 2: 9-26. Odder: Museum Tusculanum Press.

Christiansen, Eric. 1992. The Works of Sven Aggesen, Twelfth-Century Danish Historian. London: Viking Society for Northern Research.

Christiansen, Eric. 2012. "Sueno Aggonis." In: Medieval Nordic Literature in Latin, ed. Borgehammar et al. https://wikihost.uib.no/medieval/index.php/Medieval_Nordic_Litera ture_in_Latin (1 October 2020).

Conti, Aidan. 2010. "Alnoth of Canterbury and early mythopoesis in Denmark." In: Saints and Their Lives on the Periphery: Veneration of Saints in Scandinavia and Eastern Europe (c. 1000-1200), ed. Haki Antonsson \& Ildar H. Garipzanov, 189-218. Turnhout: Brepols.

Curtius, Ernst Robert. 1961 [1948]. Europäische Literatur und lateinisches Mittelalter. $3^{\text {rd }}$ ed. Bern: Francke.

Doyle, Anthony I. 1989. "Publication by members of the religious orders." In: Book Production and Publishing in Britain, 1375-1475, ed. Jeremy Griffiths \& Derek Pearsall, 109-123. Cambridge: Cambridge University Press.

Dunning, Andrew. 2016. Alexander Neckam's Manuscripts and the Augustinian Canons of Oxford and Cirencester. Unpublished PhD Diss., University of Toronto.

Ebbesen, Sten. 2012. "Andreas Sunonis." In: Medieval Nordic Literature in Latin, ed. Borgehammar et al. https://wikihost.uib.no/medieval/index.php/Medieval_Nordic_Literature_in_Latin (1 October 2020).

Eisenstein, Elizabeth. 2016 [1983]. The Printing Revolution in Early Modern Europe. $2^{\text {nd }}$ ed. Cambridge: Cambridge University Press.

Friis-Jensen, Karsten. 1989. "Was Saxo Grammaticus a canon of Lund.” Cahiers de l'Institut du moyen-âge grec et latin, 59: 331-357.

Friis-Jensen, Karsten. 2006. "Saint Canute the duke in Saxo." In: The Making of Christian Myths in the Periphery of Latin Christendom (c. 1000-1300), ed. Lars Boje Mortensen, 195-216. Odder: Museum Tusculanum Press.

Friis-Jensen, Karsten. 2012. “Robertus Elgensis.” In: Medieval Nordic Literature in Latin, ed. Borgehammar et al. https://wikihost.uib.no/medieval/index.php/Medieval_Nordic_Litera ture_in_Latin (1 October 2020).

Gelting, Michael. 2011. "Two early twelfth-century views of Denmark's Christian past: Ailnoth and the Anonymous of Roskilde." In: Historical Narratives and Christian identity on a European 
Periphery: Early History Writing in Northern, East-Central, and Eastern Europe (c. 1070-1200), ed. Ildar H. Garipzanov, 33-55. Turnhout: Brepols.

Gertz, Martinus Clarentius. 1907. Knud den helliges Martyrhistorie. Copenhagen: Universitets bogtrykkeri.

Gullick, Michael. 2011. "Palaeographical observations on four medieval fragments of the Gesta Danorum of Saxo Grammaticus in The Royal Library." Fund og Forskning i det Kongelige Biblioteks Samlingar 50: 65-77.

Hayward, Paul A. 2004. "Some reflections on the historical value of the so-called Acta Lanfranci." Historical Research, 77: 141-160.

Hobbins, Daniel. 2013. Authorship and Publicity before Print: Jean Gerson and the Transformation of Late Medieval Learning. Philadelphia: University of Pennsylvania Press.

Kristensen, Anne K. G. 1969. Danmarks aeldste annalistik: Studier over lundensisk annalskrivning i 12. og 13. århundrede. Copenhagen: Nordisk forlag.

Laidlaw, James C. 1987. “Christine de Pizan: a publisher’s progress.” Modern Language Review 82: $35-75$.

Medieval Nordic Literature in Latin, ed. Stephan Borgehammar, Karsten Friis-Jensen, Lars Boje Mortensen \& Åslaug Ommundsen, 2012. https://wikihost.uib.no/medieval/index.php/Medie val_Nordic_Literature_in_Latin (1 October 2020).

Mortensen, Lars Boje. 1995. "Stylistic choice in a reborn genre: National histories of Widukind of Corvey and Dudo of St. Quentin." In: Dudone di San Quintino, ed. Paolo Gatti \& Antonella Degl'Innocenti, 77-102. Trento: Dipartimento di scienze filologiche e storiche, Università degli studi di Trento.

Mortensen, Lars Boje. 2006. "Sanctified beginnings and mythopoetic moments." In: The Making of Christian Myths in the Periphery of Latin Christendom (c. 1000-1300), ed. Lars Boje Mortensen, 247-273. Odder: Museum Tusculanum Press.

Mortensen, Lars Boje. 2011. "Historia Norwegie and Sven Aggesen: two pioneers in comparison." In: Historical Narratives and Christian identity on a European Periphery: Early History Writing in Northern, East-Central, and Eastern Europe (c. 1070-1200), ed. Ildar H. Garipzanov, 57-70. Turnhout: Brepols.

Mortensen, Lars Boje. 2012. "Sanctus Olavus." In: Medieval Nordic Literature in Latin, ed. Borgehammar et al. https://wikihost.uib.no/medieval/index.php/Medieval_Nordic_Litera ture_in_Latin (1 October 2020).

Mortensen, Lars Boje. 2019. Saxo. Aarhus: Aarhus Universitetsforslag.

Niskanen, Samu. 2016. "The treatises of Ralph of Battle.” The Journal of Medieval Latin 26: 199-225.

Niskanen, Samu. 2019. "Copyists and redactors: Towards a prolegomenon to the editio princeps of Peregrinatio Antiochie per Vrbanum papam facta." In: Transmission of Knowledge in the Late Middle Ages and the Renaissance, ed. Outi Merisalo, Miika Kuha \& Susanna Niiranen, 103-114. Turnhout: Brepols.

Ommundsen, Åslaug. 2012. "Sanctus Hallvardus." In: Medieval Nordic Literature in Latin, ed. Borgehammar et al. https://wikihost.uib.no/medieval/index.php/Medieval_Nordic_Litera ture_in_Latin (1 October 2020).

Regnicoli, Laura. 2013. "I testamenti di Giovanni Boccaccio, in Boccaccio autore e copista." In: Catalogo della mostra Firenze, Biblioteca Medicea Laurenziana, 11 ottobre 2013-13 gennaio 2014, ed. Teresa De Robertis, Carla Maria Monti, Marco Petoletti, Giuliano Tanturli, \& Stefano Zamponi, 387-393. Florence: Mandragora.

Riddy, Felicity. 2004. "'Publication' before print: The case of Julian of Norwich.” In: The Uses of Script and Print, 1300-1700, ed. Julia C. Crick and Alexandra Walsham, 29-49. Cambridge: Cambridge University Press. 
Root, Robert K. 1913. "Publication before printing." Publications of the Modern Language Association 28: 417-431.

Sharpe, Richard. 1995. "The setting of St Augustine's translation, 1091." In: Canterbury and the Norman Conquest: Churches, Saints, and Scholars, 1066-1109, ed. Richard Eales \& Richard Sharpe, 1-14. London: Hambledon Press.

Sharpe, Richard. 2009. "Anselm as author: Publishing in the late eleventh century." Journal of Medieval Latin 19: 1-87.

Ståhl, Peter. 2012. "Sanctus Botvidus." In: Medieval Nordic Literature in Latin, ed. Borgehammar et al. https://wikihost.uib.no/medieval/index.php/Medieval_Nordic_Literature_in_Latin (1 October 2020).

Sønnesyn, Sigbjørn. 2016. "Monastic life as a matrix of meaning: History, liturgy, and interior reform in early Danish historical texts." In: Historical and intellectual culture in the long twelfth century: the Scandinavian connection, ed. Mia Münster-Swendsen, Thomas K. HeebøllHolm \& Sigbjørn Sønnesyn, 131-47. Durham: Institute of Medieval and Early Modern Studies, Durham University.

Tahkokallio, Jaakko. 2019. The Anglo-Norman Historical Canon: Publishing and Manuscript Culture. Cambridge: Cambridge University Press.

Tether, Leah. 2014. "Revisiting the manuscripts of Perceval and the continuations: Publishing practices and authorial transition." Journal of the International Arthurian Society 2: 20-45.

Tether, Leah. 2017. Publishing the Grail in Medieval and Renaissance France. Woodbridge: Boydell and Brewer.

Winterbottom, Michael. 2016. "The style of Ælnoth.” In: Historical and intellectual culture in the long twelfth century: the Scandinavian connection, ed. Mia Münster-Swendsen, Thomas K. Heebøll-Holm \& Sigbjørn Sønnesyn, 119-130. Durham: Institute of Medieval and Early Modern Studies, Durham University. 
